\title{
PRODUKSI OLIGOMER KITOSAN SECARA ENZIMATIS DAN UJI BIOAKTIVITASNYA TERHADAP KAPANG HASIL ISOLASI DARI PRODUK PERIKANAN
}

\author{
Ekowati Chasanah"), Trie Anis Riviyanti"*), dan Nita Noriko"*)
}

\begin{abstract}
ABSTRAK
Kitosan dalam bentuk potongan yang disebut oligomer kitosan, bersifat larut air sehingga memudahkan aplikasinya, dan meminimalkan gangguan sensoris akibat sifat kitosan yang hanya larut dalam asam lemah seperti asam asetat. Tujuan penelitian ini adalah untuk memproduksi oligomer kitosan dengan katalisator enzim kitosanase yang diperoleh dari isolat bakteri Stenotrophomonas malthopilia KPU 2123 dan menguji bioaktivitas oligomer yang dihasilkannya terhadap kapang Aspergillus niger, Aspergillus flavus, Nigrospora oryzae B12, dan Aspergillus fumigatus $\mathrm{C} 13$ yang diisolasi dari produk perikanan. Produksi oligomer dilakukan dengan menggunakan enzim kitosanase sebesar $8 \mathrm{U} / \mathrm{g}$ kitosan dan direaksikan selama 1, 2, 3, dan 4 jam pada suhu ruang. Pengamatan dilakukan terhadap viskositas, rendemen, dan jenis oligomer kitosan yang terbentuk. Identifikasi oligomer dilakukan dengan Kromatografi Lapis Tipis (KLT). Pengujian bioaktivitas oligomer kitosan dilakukan terhadap 4 kapang konsentrasi 50, 100, dan 200 ppm, dengan kontrol tanpa penambahan oligomer. Hasil penelitian menunjukkan bahwa enzim kitosanase kasar dari Stenotrophomonas malthopilia KPU 2123 dapat digunakan untuk menghidrolisis kitosan menjadi oligomer kitosan, yang ditandai oleh menurunnya viskositas yang sangat signifikan pada larutan kitosan. Dengan menggunakan enzim kitosanase kasar $8 \mathrm{U} /$ g kitosan, kitosan oligomer dapat diproduksi dengan waktu reaksi 2 jam, penghentian reaksi enzimatis dapat dilakukan dengan pendidihan selama 15 menit atau dengan penambahan $\mathrm{NaOH}$ sampai netral. Jenis oligomer yang terbentuk adalah dimer (2 unit) hingga heksamer (6 unit). Uji bioaktivitas antikapang menunjukkan bahwa setiap perlakuan memberikan perbedaan yang nyata pada penghambatan pertumbuhan kapang apabila dibandingkan dengan kontrol. Namun tidak ada perbedaan yang nyata dalam penghambatan pertumbuhan kapang yang diuji jika digunakan oligomer kitosan sebesar 50 dan 100 ppm. Penghambatan yang terbaik adalah jika digunakan oligomer dengan konsentrasi $200 \mathrm{ppm}$.
\end{abstract}

KATAKUNCl: $\quad$ bakteri KPU 2123, oligomer kitosan, bioaktivitas, kapang

ABSTRACT : Production of chitosan oligomer enzymatically and its bioactivity against fungi isolated from fishery products. By: Ekowati Chasanah, Trie Anis Riviyanti and Nita Noriko

Chitosan, in the form of shorter size called oligomer, is soluble in the water, making it easier to apply and minimize soury odor problem since chitosan is only soluble to weak acid such as acetic acid. Aims of this research was to produce chitosan oligomer using Stenotrophomonas malthopilia KPU 2123 chitosanase and assess bioactivity of the oligomer against Aspergillus niger, Aspergillus flavus, Nigrospora oryzae B12 and Aspergillus fumigatus C13. Oligomer production was done using $8 U$ of chitosanase per gram chitosan, with reaction time of 1,2, 3 and 4 hours at room temperature. Viscosity of the mixture and yield of the oligomer formed were analysed. Identification of the oligomer produced was done using thin layer chromatography (TLC). Bioactivity study of oligomer in concentration of 50,100 and $200 \mathrm{ppm}$ was done against 4 fungi and control without addition of oligomer. Results showed that Stenotrophomonas malthopilia KPU 2123 crude chitosanase was able to hydrolyse chitosan, reduce the viscosity significantly. Using $8 \mathrm{U} / \mathrm{g}$ chitosan, oligomer chitosan can be produced for 2 hours, using $\mathrm{NaOH}$ until neutral or boiling for 15 minutes to stop reaction. Oligomer formed was dimer (2 unit) to hexamer (6 unit). Bioactivity test resulted a significant growth inhibition of the oligomer (50-200 ppm) against the four fungi tested. However, there was no significantly different between oligomer in concentration of 50 and $100 \mathrm{ppm}$. The best inhibition was achieved by using oligomer in the concentration of $200 \mathrm{ppm}$.

KEYWORDS: bacteria KPU 2123, chitosan oligomer, bioactivity, fungi

7) Peneliti pada Balai Besar Penelitian dan Pengembangan Pengolahan Produk dan Bioteknologi Kelautan dan Perikanan, Balitbang KP, KKP; JI. KS. Tubun Petamburan VI, Slipi Jakarta. E-mail: ekowati_ch@yahoo.com

*) Jurusan Biologi (Bioteknologi), Universitas Al Azhar Komplek Masjid Agung AI Azhar, Jakarta. 


\section{PENDAHULUAN}

Potensi aplikasi kitosan yang luas pada berbagai industri serta sifat bioaktivitasnya, kitosan memiliki kelemahan, di antaranya memiliki sifat tidak larut dalam air tetapi hanya larut dalam asam lemah seperti asam asetat. Kelemahan tersebut menghambat aplikasinya misalnya apabila akan diaplikasikan ke dalam produk pangan maka hanya akan cocok untuk produk yang tidak terganggu dengan odor/bau asam dari larutan kitosan. Salah satu produk turunan kitosan yang memiliki aplikasi yang lebih luas adalah kitosan larut air yang dapat diperoleh dengan memodifikasi kitosan secara kimia atau rantai polimer kitosan dipotong sehingga memiliki rantai yang lebih pendek yang disebut oligomer kitosan. Aplikasi oligomer kitosan di bidang farmasi dan obat serta bidang pertanian diperkirakan masih menjadi bidang yang sangat menjanjikan di waktu ini dan yang akan datang, selain aplikasinya dalam bidang nanoteknologi (Khoushab \& Yamabhai, 2010)

Dalam bentuk rantai pendek oligomer ini, aktivitas biologis kitosan masih dapat dipertahankan, bahkan beberapa di antaranya memiliki aktivitas biologis yang lebih baik. Oligomer kitosan atau oligosakarida dilaporkan masih menjadi fokus dan menjadi tren riset saat ini karena memiliki beberapa bioaktivitas yang sangat menarik, di antaranya sebagai penyembuh luka, antimikroba, penghambat pertumbuhan, dan metastase tumor, penginduksi produksi interleukin 1 dan 2 (Khoushab \& Yamabhai, 2010). Oligomer kitosan telah dikenal sebagai pengontrol penyakit tanaman yang aman dan ramah lingkungan, oligomer kitosan yang berukuran 6 unit (hexamer) telah dilaporkan memiliki sifat anti beberapa kapang tanaman seperti Fusarium solani (Zhang et al., 2001), dan Phytophthora capsici (Xu et al., 2007). Aktivitas kitosan dengan berbagai berat molekul dan konsentrasi telah dilaporkan mampu menghambat kapang Aspergillus niger (Fang et al., 2008) yang merupakan kapang umum perusak pangan dan komoditas pertanian. Potensi oligomer kitosan sebagai produk bernilai tambah tinggi dan aplikasinya telah disampaikan oleh Chasanah (2010).

Kapang merupakan salah satu perusak pangan bahkan beberapa menjadi penghasil toksin penyebab keracunan pada manusia dan hewan seperti $A$. flavus. Keberadaan kapang pada beberapa produk perikanan, terutama produk tradisional seperti ikan asin, ikan pindang, ikan asap, dan produk fermentasi seperti peda perlu mendapat perhatian karena dikonsumsi secara luas oleh masyarakat Indonesia. Perannya dalam mencukupi gizi masyarakat sangat penting tetapi dibatasi oleh daya awet produk sehingga sering terjadi loss yang cukup tinggi, bahkan kadang menyebabkan keracunan sehingga termasuk dalam jenis olahan ikan yang mendapat prioritas pengawasan di POM (Rahayu, 2010). Upaya untuk mendapatkan pengawet alami yang mudah diproduksi dan relatif murah sangat diperlukan untuk mengurangi lossess dan bahaya keracunan akibat mikroorganisme.

Bakteri KPU 2123 merupakan salah satu isolat bakteri yang berpotensi dan diisolasi dari limbah udang (Chasanah et al., 2009). Enzim kitosanase dari bakteri S. malthopilia KPU 2123 ini bekerja optimal pada $\mathrm{pH} 6$ dan suhu $50^{\circ} \mathrm{C}$ tetapi stabil pada suhu $37^{\circ} \mathrm{C}$, dihambat oleh adanya ion $\mathrm{Zn}^{2+}$. Pembuatan oligomer kitosan telah dilakukan dengan menggunakan enzim kitosanase kasar sebesar $23 \mathrm{U} / g$ kitosan, dan produksinya mampu menghambat $10 \%$ pertumbuhan S. aureus dan sel Hela dengan $I C_{50}$ pada dosis 120 ppm (Fawzya et al., 2009). Dalam penelitian lanjutan ini, uji coba produksi oligomer kitosan masih akan dilakukan dengan lebih mengefisiensikan enzim yaitu dengan jumlah enzim yang lebih rendah dan melihat cara penghentian reaksi yang lebih baik. Tujuan penelitian ini adalah mendapatkan teknik produksi oligomer kitosan dengan menggunakan enzim dari isolat lokal yaitu S. malthopilia KPU 2123 dan menguji bioaktivitasnya terhadap kapang-kapang perusak produk perikanan yang diantaranya bersifat patogen.

\section{BAHAN DAN METODE}

\section{Produksi Enzim}

Produksi enzim didahului dengan penyegaran isolat bakteri KPU 2123 yang dilakukan pada media MSM (Minimum Synthetic Medium) padat yang berisi $0,1 \% \mathrm{~K}_{2} \mathrm{HPO}_{4} ; 0,01 \% \mathrm{MgSO}_{4} .7 \mathrm{H}_{2} \mathrm{O} ; 0,1 \% \mathrm{NaCl}$; $0,07 \%\left(\mathrm{NH}_{4}\right)_{2} \mathrm{SO}_{4} ; 0,05 \%$ yeast extract; koloidal kitin $1 \%$; dan agar $1,5 \%$. Produksi enzim ekstraselular dilakukan dengan mengkultur bakteri penghasil enzim dalam media MSM cair pada fermentor kapasitas 3 L. Enzim kitosanase yang diperoleh selanjutnya dipekatkan dengan ultrafiltrasi yang memiliki cut off $10 \mathrm{kDa}$.

\section{Produksi Oligomer Kitosan}

Produksi oligomer kitosan dilakukan dengan mereaksikan $8 \mathrm{U}$ enzim kasar/g kitosan dengan 50 $\mathrm{mL} 2 \%$ soluble kitosan. Hidrolisis diikuti dengan mengukur viskositas sebelum dan setelah penambahan enzim pada 0, 1, 2, 3, dan 4 jam reaksi. Kontrol adalah larutan kitosan tanpa penambahan enzim. Pengukuran viskositas dilakukan dengan menggunakan viskometer (Brookfield Synchro-lectric). Penurunan viskositas dihitung menurut Muzzarelli et al. (1995). Penghentian reaksi enzimatik dilakukan dengan 2 cara yaitu 1) merebus larutan selama 10 
menit dalam penangas air (Choi et al., 2004); 2) menambahkan $0,25 \mathrm{~mL} \mathrm{NaOH} 0,05 \mathrm{~N}$ hingga $\mathrm{pH} 7$. Selanjutnya sampel disentrifugasi pada suhu $37^{\circ} \mathrm{C}$ selama 20 menit pada kecepatan $9.000 \mathrm{~g}$, dan supernatan yang mengandung oligomer kitosan selanjutnya dikeringbekukan dengan freeze dryer. Rendemen dihitung berdasarkan dari pengurangan berat (kering) sampel yang mendapat perlakuan enzim dengan berat (kering) sampel yang tidak mendapat perlakuan enzim, dibagi dengan berat awal kitosan yang digunakan sebagai bahan baku dan hasilnya dikalikan $100 \%$.

\section{Pengujian Bioaktivitas}

Uji bioaktivitas oligomer dilakukan terhadap jenis A. flavus, A. niger, isolat $\mathrm{B} 12$, dan isolat $\mathrm{C} 13$ menurut metode Xu et al. (2007). Kapang tersebut merupakan koleksi Laboratorium Mikrobiologi BBP4BKP. Hasil identifikasi secara molekuler terhadap isolat B12 dan C13 tersebut adalah isolat tersebut memiliki kemiripan 99\% terhadap Nigrospora oryzae (untuk B12) dan A. fumigatus (untuk C13). Sebelum dilakukan pengujian, kapang-kapang tersebut disegarkan dalam media agar miring Malt Ekstrak Agar (MEA) yang memiliki komposisi $0,3 \%$ malt extract; $0,3 \%$ ekstrak yeast, $0,5 \%$ pepton; $1,5 \%$ agar; dan diinkubasi selama 5 hari pada inkubator dengan suhu $28^{\circ} \mathrm{C}$. Masingmasing kapang selanjutnya dihomogenkan dengan 0,05\% larutan Tween 80 dan 0,2\% agar, sebelum ditotolkan pada media yang telah diberi perlakuan oligomer. Persiapan oligomer dilakukan dengan melarutkan oligomer dalam akuades, dan disterilkan dengan melalukan pada kertas saring yang memiliki ukuran pori 0,22 $\mu \mathrm{M}$. Oligomer ditambahkan secara aseptis pada media MEA hangat steril sedemikian sehingga memiliki konsentrasi akhir 50, 100, dan 200 ppm, kemudian dicampurkan dan dibiarkan dingin sampai siap untuk diinokulasi dengan kapang. Kapang selanjutnya ditumbuhkan dengan cara ditotolkan di tengah media MEA kemudian diinkubasi pada suhu $28^{\circ} \mathrm{C}$ selama 3 hari. Pengujian dilakukan dengan 2 ulangan. Data diolah dengan menggunakan uji ANOVA satu arah. Faktor perlakuan yang berbeda nyata menurut uji ANOVA dilanjutkan dengan uji Beda Nyata Terkecil (BNT) pada taraf $\alpha=5 \%$ untuk melihat perbedaan antara taraf perlakuan dan interaksinya.

\section{Identifikasi Oligomer Kitosan}

Oligomer kitosan diidentifikasi dengan menggunakan kromatografi lapisan tipis (KLT) berdasarkan metode Choi et al. (2004). Larutan pengembang disiapkan dengan menggunakan campuran 1-propanol, $25 \%$ amonia, dan akuades dengan perbandingan (60:9:21) kemudian dituangkan ke dalam chamber KLT dan didiamkan hingga larutan homogen didalam chamber KLT tersebut. Oligomer kitosan yang telah dikeringbekukan diencerkan sebesar 10.000 ppm kemudian ditotolkan pada plat Silicagel $60 \mathrm{GF}_{254}$ (Merck). Spot sampel yang terbentuk dapat dibaca setelah disemprot dengan $0,1 \%$ ninhidrin dalam butanol, setelah dikeringkan kemudian sampel dipanaskan dalam oven $100^{\circ} \mathrm{C}$ selama 10 menit. Sebagai standar digunakan kitooligosakarida yang mengandung monomer sampai heksamer (Seikagaku, Jepang).

\section{HASIL DAN BAHASAN}

\section{Produksi Enzim dan Oligomer Kitosan}

Enzim kitosanase kasar yang diproduksi dalam skala $1 \mathrm{~L}$ memiliki aktivitas $0,131 \mathrm{U} / \mathrm{mL}$ atau $0,829 \mathrm{U} /$ $\mathrm{mg}$, yang setelah dipekatkan dengan ultrafiltrasi memiliki aktivitas $1,004 \mathrm{U} / \mathrm{mL}$ atau $1,463 \mathrm{U} / \mathrm{mg}$. Tabel 1 memperlihatkan nilai viskositas hasil hidrolisis enzim kitosanase kasar (8 U/g kitosan) dari S. malthopilia KPU 2123.

Dari Tabel 1 terlihat bahwa enzim kasar yang ditambahkan mampu menurunkan viskositas kitosan sebesar 90,93-95,46\%, yang ditandai dengan semakin encernya larutan kitosan. Kontrol (kitosan

Tabel 1. Nilai viskositas oligomer kitosan isolat bakteri KPU 2123

Table 1. Viscosity value of bacteri isolate chitosan oligomer KPU 2123

\begin{tabular}{cc}
\hline $\begin{array}{c}\text { Waktu Reaksi (jam)l } \\
\text { Reaction Time (hour) }\end{array}$ & $\begin{array}{c}\text { Viskositas I } \\
\text { Viscosity (cPs) }\end{array}$ \\
\hline Kontrol (tanpa enzim)/Control (no enzym) & $187 \pm 0.50$ \\
0 & $133 \pm 0.25$ \\
1 & $16 \pm 0.50$ \\
2 & $14 \pm 0.25$ \\
3 & $10 \pm 0.10$ \\
4 & $9 \pm 0.50$ \\
\hline
\end{tabular}


sedangkan Fawzya et al. (2009) menggunakan kitosan Sigma. Perbedaan antara kitosan Sigma dan kitosan lokal adalah pada derajat deasetilasi (DA) yang diukur dengan FTIR; kitosan IPB memiliki DA 51,44\%, sedangkan kitosan Sigma memiliki DA 52,32\% (yang tercantum di label $>85 \%$ (Chasanah et al., 2010). Kemungkinan lain adalah rantai polimer kitosan yang diproduksi IPB tersusun sedemikian rupa sehingga lebih memudahkan akses sehingga enzim menjadi lebih baik kinerjanya.

Pada jam pertama terjadi hidrolisis terbesar, oligomer ukuran 2-6 sudah dapat terdeteksi dengan pita oligomer ukuran kecil yang lebih tebal dibandingkan dengan yang berukuran besar. Hal ini konsisten diikuti oleh hasil reaksi pada jam reaksi 2 4 (Gambar 1). Apabila dihubungkan dengan rendemen, maka rendemen terbesar adalah pada waktu reaksi 4 jam, dengan hasil oligomer yang lebih banyak dibanding jika digunakan waktu reaksi yang lebih pendek, dengan jenis campuran oligomer yang kurang lebih sama yaitu 2-6 unit, yang di dominasi ukuran 2 unit. Karena itu, waktu produksi $2-4$ jam merupakan pilihan.

Inaktifasi dengan dua cara yaitu pemanasan dan penetralan tidak menunjukkan perbedaan hasil, baik rendemen maupun jenis, meskipun produk oligomer kitosan yang diinaktifasi dengan $\mathrm{NaOH}$ memiliki kecenderungan menghasilkan pewarnaan bercak pada KLT yang lebih jelas (Gambar 1). Ditimbang dari kepraktisan dan sifat produk akhirnya, maka penetralan nampaknya merupakan pilihan apalagi bila diproduksi dalam skala besar. Penghentian reaksi dengan menggunakan panas akan membebani biaya produksi.

Berbagai enzim dilaporkan mampu menghasilkan oligomer kitin/kitosan dengan jenis yang berbeda-beda karena masing-masing enzim mempunyai pola hidrolisis yang berbeda satu dengan yang lain, tergantung dari spesifisitas enzim tersebut. Tingkat deasetilasi substrat juga akan mempengaruhi kualitas oligomer, karena kualitas dan aplikasinya tergantung dari gugus aktif nya, semakin tinggi tingkat deasetilasi kitosan yang digunakan sebagai bahan baku, semakin bagus kualitas oligomer yang dihasilkan (Dahiya et al., 2006; Hayes et al., 2008). Dengan menggunakan enzim kitosanase murni dari Bacillus licheniformis MB-2, oligomer yang terbentuk adalah 5-6 unit dengan dominasi ukuran 6 unit, dan ketika digunakan enzim kasar maka telah dihasilkan oligomer kitosan berupa campuran berbagai ukuran (Chasanah et al., 2006). Hidrolisis dengan enzim protease mampu menghasilkan oligomer dengan derajat polimerisasi 3-8 ( $\mathrm{Li}$ et al., 1997), pronase mampu menghasilkan oligomer dengan derajat polimerisasi $2-6$ dan selulase juga mampu menghasilkan oligomer dengan derajat polimerisasi 2-6 (Sitohang, 2008). Hidrolisis menggunakan enzim kasar tidak bersifat spesifik, hasil yang diperoleh masih berupa campuran yang nampaknya akan didominasi oleh oligomer ukuran tertentu tergantung dari lama hidrolisis serta jenis dan kekuatan enzim yang ada dalam enzim kasar tersebut.

\section{Uji Bioaktivitas Oligomer Kitosan Terhadap Kapang}

Uji bioaktivitas oligomer kitosan dengan konsentrasi 50, 100, dan, 200 ppm menunjukkan bahwa pemberian oligomer kitosan berpengaruh nyata terhadap penghambatan pertumbuhan kapang A. niger, $A$. flavus, isolat kapang $\mathrm{B} 12$, dan isolat kapang $\mathrm{C} 13(p<0,05)$. Hal ini dapat dilihat dari berkurangnya diameter kapang yang tumbuh pada media MEA (Gambar 2).

Hasil uji ANOVA menunjukkan terjadinya interaksi yang signifikan $(p<0,05)$ antara konsentrasi oligomer kitosan dengan penghambatan pertumbuhan kapang A. niger, $A$. flavus, isolat kapang $\mathrm{B} 12$, dan isolat kapang C13. Dari hasil uji BNT diketahui bahwa perlakuan pemberian konsentrasi 50, 100, dan 200 ppm berbeda nyata dengan kontrol. Namun pada konsentrasi 50 ppm dengan 100 ppm menunjukkan hasil yang tidak berbeda nyata dan perlakuan yang menunjukkan penghambatan yang terbaik terhadap kapang adalah pada konsentrasi 200 ppm.

Oligomer kitosan memiliki kemampuan menghambat pertumbuhan beberapa kapang dan bakteri (Uchida et al., 1988). Sifat aktif oligomer kitosan terhadap kapang disebabkan karena beberapa mekanisme, di antaranya adalah oligomer kitosan mempunyai kemampuan untuk menghambat pertumbuhan hifa dan germinasi spora (Zhang, 2001). Zhang (2001) melaporkan bahwa penggunaan oligomer kitosan dapat menghambat pertumbuhan hifa dan menghambat germinasi spora Botrytis cinerea dan Fusarium oxysporum pada tanaman tomat. Oligomer kitosan bersifat polikationik sehingga dapat menyebabkan penghambatan pertumbuhan miselium kapang, menghambat pelepasan zoospora, dan menyebabkan kerusakan vakuola dan sistem endromembran. Selanjutnya dilaporkan bahwa oligomer kitosan dapat menghambat pertumbuhan miselium dan perusakan vakuola dan plasmalemma yang terdapat pada Phytophtora capsici (Xu et al., 2007).

Li et al. (2008) melaporkan bahwa berat molekul dan konsentrasi kitosan merupakan komponen yang penting dalam menentukan keefektifan oligomer kitosan dalam menghambat pertumbuhan $A$. niger. Kitosan berukuran kecil (oligomer) berbobot molekul 


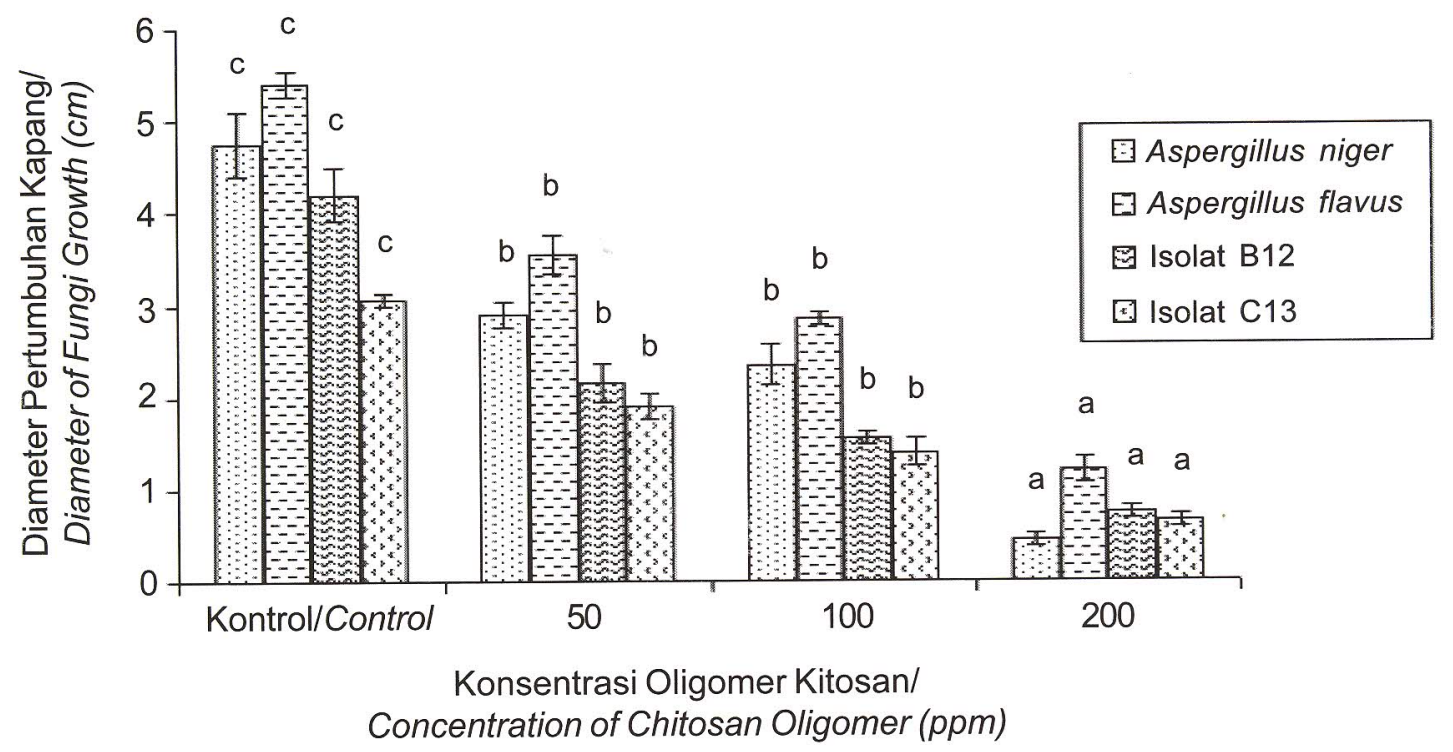

Gambar 2. Diameter pertumbuhan kapang A. niger, A. flavus, isolat kapang B12, dan isolat kapang C13 setelah media pertumbuhannya diberi oligomer kitosan 50,100 , dan $200 \mathrm{ppm}$. Nilai adalah rerata $\pm S D, n=2$. Grafik batang yang memiliki notasi huruf yang berbeda menandakan nilai yang berbeda berdasarkan uji BNT $\alpha=5 \%$.

Figure 2. Fungi growth diameter of A. niger, A. flavus, isolate B12 and C13 in medium added with 50, 100 and $200 \mathrm{ppm}$ of chitosan oligomer. The values shown was an average $\pm S D, n=2$. Histogram with diffferent letter showed statistically different results based on $\alpha=5 \%$.

$50 \mathrm{kDa}$ dengan konsentrasi aplikasi $0,2 \%$ ternyata memiliki kemampuan penghambatan terbesar. Penghambatan juga tidak bersifat linier sesuai dengan konsentrasi aplikasi kitosan seperti yang selama ini dilaporkan, juga yang dilaporkan pada hasil penelitian ini. Dari konsentrasi yang dicobakan pada penelitian ini yaitu 50, 100, dan 200 ppm, maka penghambatan terbesar diperoleh pada konsentrasi terbesar yang dicobakan yaitu 200 ppm. Karena itu, perlu dicobakan penggunaan konsentrasi yang lebih besar dari 200 ppm untuk membuktikan hasil Li et al. (2008) bahwa kemampuan penghambatan tidak bersifat linier.

\section{KESIMPULAN}

Dengan menggunakan enzim kitosanase kasar dari bakteri S. malthopilia KPU 2123, oligomer kitosan dapat diproduksi dalam waktu 2-4 jam, menggunakan enzim dengan kekuatan $8 \mathrm{U} / \mathrm{g}$ kitosan dengan penghentian reaksi melalui pendidihan selama 15 menit atau dengan penambahan $\mathrm{NaOH}$ sampai netral. Dengan waktu reaksi tersebut, rendemen yang diperoleh adalah sebesar $48-50 \%$ dan oligomer berukuran campuran dimer hingga heksamer.

Uji bioaktivitas antikapang dengan pemberian konsentrasi oligomer kitosan 50-200 ppm menunjukkan penghambatan secara nyata terhadap pertumbuhan kapang apabila dibandingkan dengan kontrol. Namun penghambatan terhadap pertumbuhan kapang $A$. niger, $A$. flavus, isolat kapang $B 12$, dan isolat kapang $\mathrm{C} 13$ yang tidak berbeda nyata terjadi pada konsentrasi $50 \mathrm{ppm}$ dengan $100 \mathrm{ppm}$ dan penghambatan yang terbaik adalah pada konsentrasi 200 ppm.

\section{UCAPAN TERIMA KASIH}

Penulis menyampaikan terima kasih kepada Dra. Ninoek Indriati yang telah memberikan koleksi isolat kapang untuk penelitian ini.

\section{DAFTAR PUSTAKA}

Chasanah, E., Hariyadi, P., Witarto, A.B., Hwang, J.K, and Suhartono, M.T. 2006. Biochemical Characteristic of Chitosanase from the Indonesian $B$. licheniformis MB-2. Journal of Molecular Biotechnology. 33(2): 93102.

Chasanah, E., IImi, M., dan Mangunwardoyo, W. 2009. Penapisan bakteri kitinolitik dari limbah pengolahan udang. Jurnal Pascapanen dan Bioteknologi Kelautan dan Perikanan. 4(1): 59-68.

Chasanah, E. 2010. Pengembangan produk kitooligosakarida dari limbah industri perikanan udang secara enzimatis: prospek dan kendala. Buletin Pascapanen dan Bioteknologi Kelautan dan Perikanan. 5(2): 44-50. 
Chasanah, E., Fawzya, Y.N., Poernomo, A., Munifah, I., Dewi, A.S., Pratitis, A., dan Patantis, G. 2010. Penelitian pemanfaatan mikroorganisme dan enzim untuk pengembangan produk berbasis surimi tropical catfish, bioenergi dari limbah rumput laut dan nutrasetikal dari limbah udang. Laporan Teknis. Balai Besar Riset Pengolahan Produk dan Bioteknologi kelautan dan Perikanan.

Choi, Y.C, Kim, E.J., and Shin, Y.C. 2004. Purification and characterization of chitosanase from Bacillus sp. strain KCTC 0377BP and application for the production of chitosan oligosaccarides. Appl. Eviron. Mirobiol. 70: 4522-31.

Dahiya, N., Tewari, R., and Hoondal, G.S. 2006. Biotechnological aspects of chitinolytic enzymes: a review. Appl Microbiol Biotechnol. 71(6):773-82.

Fang, L.X, Feng, X.Q., Yang, S., Wang, T.P., and Su, Z.X. 2008. Effects of molecular weight and concentration of chitosan on antifungal activity against Aspergillus niger. Iranian Polymer Journal. 17(11): 843-852.

Fawzya, Y.N., Pratitis, A., dan Chasanah, E. 2009. Karakterisasi enzim kitosanase dari isolat bakteri KPU 2123 dan aplikasinyanya untuk produksi oligomer kitosan. Jurnal Pascapanen dan Bioteknologi Kelautan dan Perikanan. 4(1): 69-78.

Hayes, M., Carney, B., Slater, J., and Brück W. 2008. Mining marine shellfish wastes for bioactive molecules: chitin and chitosan-Part A: extraction methods. Biotechnol Journal. 3(7):871-877.

Khoushab, F. and Yamabhai, M. 2010. Chitin research revisited. Marine Drugs. 8: 1988-2012.

Li, Q., Dunn, E.T., Grandmaison, E.W., and Goosen, M.F.A. 1997. Application and properties of chitosan. In
Goosen, M.F.A. (ed.). Application of Chitin and Chitosan. Technomic Publishing Company, Switzerland. p. 5-9.

Li, X.F., Feng, X.Q., Yang, S., Wang, T.P., and and Su, Z.X. 2008. Effects of MolecularWeight and Concentration of Chitosan on Antifungal Activity Against Aspergillus Niger. Iranian Polymer Journal. 17(11): 843-852.

Muzzarelli, R.A.A., Xia, W., Tomasetti, M., and Ilari, P. 1995. Depolymerization of chitosan and substituted chitosans with the aid of a wheat germ lipase preparation. Enzyme and Microbial Technology. 17: 541-545.

Rahayu, W. 2010. Keamanan Hasil Perikanan. Bahan Presentasi dalam rangka. Focus Group Discussion Balai Besar Riset Pengolahan Produk dan Bioteknologi Kelautan dan Perikanan, Jakarta 29 Juni 2010.

Sitohang,M.Y. 2008. Produksi dan Uji Antibakteri Oligomer Kitosan dari Kitosan Komersial. Skripsi. Fakultas Farmasi. Universitas Pancasila, Jakarta.

Uchida, Y., Izume, M., and Ohtakara, A. 1988. Preparation of chitosan oligomer with purified chitosanase and its application. In Skjak-Braek, G., Anthosen, T. and Sandford, P. (eds.). Chitin and Chitosan. London. p. 373-382.

Xu, J., Zhao, X., Han, X., and Du, Y. 2007. Antifungal activity of oligochitosan against Phytophtora capsici and other plant pathogenic fungi in vitro. Pesticide Biochemistry and Physiology. 87: 220-228.

Zhang, Z., Yuen, G.Y., Sarath, G., and Penheiter, A.R. 2001. Chitinases from the plant disease biocontrol agent Stenotrophomonas maltopilia. Phytopathology. 91: 204-211. 